\title{
Pengaruh Motivasi Kerja Terhadap Kinerja Karyawan Dengan Kepuasan Kerja Sebagai Variabel Intervening Pada PT. Federal International Finance (FIF)
}

\author{
Eka Pariyanti $^{1}$, Rinnanik ${ }^{2}$, Tri Mardiono ${ }^{3}$ \\ STIE Lampung Timur ${ }^{1,2,3}$
}

\begin{abstract}
Fulfill all needs or desires in the employee, it will create a feeling of satisfaction, and employees with high levels of satisfaction will experience an increase in performance. Based on this matter, this study aims, (1) To determine the effect of work motivation on employee performance, (2) To determine the effect of work motivation on job satisfaction, (3) To determine the effect of job satisfaction on employee performance, (4) To determine the effect work motivation on employee performance with job satisfaction as an intervening variable. The data collection technique of this study was a questionnaire and documentation. The population of this study was employees of PT. PT. Federal International Finance (FIF), eastern Lampung region with a total of 96 people. While the data analysis uses regression analysis and phat path. The results of this study are, (1) Motivating Work Influence on Employee Performance, (2) Motivating Influential Work Against Job Satisfaction, (3) Influential Job Satisfaction on Employee Performance, (4) Job Satisfaction Role as Intervening Variables Between Work Motivation and Performance Employees (5) Work motivation influences employee performance directly, but work motivation will have greater influence on employee performance if first through or added to job satisfaction. These Research Results Can Become Input For PT. Federal International Finance (FIF), as material for consideration to improve employee performance.
\end{abstract}

Keywords: Motivation, Job Satisfaction, Employee Performance

\section{Pendahuluan}

Sumber daya manusia merupakan tokoh sentral dalam organisasi maupun perusahaan. Agar aktifitas manajemen perusahaan berjalan dengan baik, perusahaan harus memiliki karyawan yang memiliki tingkat pengetahuan dan keterampilan yang tinggi serta usaha untuk mengelola perusahaan seoptimal mungkin agar kinerja perusahaan terus meningkat (Hendrawan dan Pradhanawati, 2015). Mangkunegara (2013) mendefinisikan kinerja adalah hasil kerja secara kualitas dan kuantitas yang dicapai oleh seorang pegawai dalam melaksanakan 
tugasnya sesuai dengan tanggung jawab yang diberikan kepadanya.

Kinerja yang baik adalah kinerja yang optimal, untuk mencapai kinerja yang optimal karyawan harus memiliki dorongan dalam dirinya untuk melakukan sesuatu yang menjadi tugasnya, dorongan dalam diri inilah yang disebut motivasi. Penelitian yang dilalukan oleh Chrisnanda (2017) menyatakan bahwa motivasi berpengaruh signifikan terhadap kinerja karyawan. Sugiyono (2013) mendefinisikan motivasi adalah seperangkat faktor yang dapat membangkitkan, mengarahkan dan memelihara perilaku seseorang untuk memilih jalan tertentu dalam mencapai tujuan.

Menurut beberapa penelitian selain motivasi, kepuasan kerja juga dapat berpengaruh terhadap kinerja karyawan. Penelitian yang dilakukan oleh Prakasa (2017) menyatakan bahwa kepuasan kerja berpengaruh positif terhadap kinerja karyawan. Kepuasan kerja sendiri diartikan sebagai suatu sikap positif yang didasarkan pada hasil evaluasi terhadap apa yang diharapkan akan diperoleh melalui upaya-upaya yang dilakukan dalam melaksanakan suatu pekerjaan dengan hasil atau ganjaran yang diterimanya (Suparyadi, 2015).

Dengan terpenuhinya semua kebutuhan atau keinginan dalam diri karyawan, maka akan tercipta perasaan puas, dan karyawan yang tingkat kepuasannya tinggi maka akan mengalami peningkatan dalam kinerja. Begitu juga sebaliknya, apabila kebutuhan karyawan tidak sesuai dengan yang diharapkan dan tidak sebanding dengan hasil kerja mereka, maka tidak akan tercipta perasaan puas dalam diri karyawan sehingga hal tersebut akan membuat kinerja karyawan menurun.

Seperti pada perusahaan pada umumnya PT. Federal International Finance (FIF) juga mengalami berbagai masalah, baik masalah karyawan, masalah eksternal dan lain-lain. Dalam rangka menganilisis kinerja karyawan PT. Federal International Finance (FIF), penulis memilih untuk mengamati variabel motivasi kerja dan kepuasan kerja dengan harapan bahwa perbaikan kinerja dapat dilakukan setelah mengetahui motivasi dan kepuasan karyawan di PT. Federal International Finance (FIF). Oleh karena itu penulis tertarik untuk melakukan penelitian dengan judul "Pengaruh Motivasi Kerja Terhadap Kinerja Karyawan Dengan Kepuasan Kerja Sebagai Variabel Intervening Pada PT. Federal International 


\section{Finance (FIF)".}

Adapun tujuan penelitian ini adalah untuk mengetahui:1).Pengaruh motivasi kerja terhadap kinerja karyawan pada PT. Federal International Finance Di Lampung Timur. 2).Pengaruh motivasi kerja terhadap kepuasan kerja pada PT. Federal International Finance Di Lampung Timur. 3).Pengaruh kepuasan kerja terhadap kinerja karyawan pada PT. Federal International Finance Di Lampung Timur.4).Pengaruh motivasi kerja terhadap kinerja karyawan dengan kepuasan kerja sebagai variabel intervening pada PT. Federal International Finance Di Lampung Timur.

\section{Tinjauan Pustaka}

\section{Motivasi Kerja}

Menurut Fernet (2012:208) motivasi adalah motif yang dikaitkan dengan keinginan seseorang untuk melakukan sesuatu atau tidak. Motivasi umumnya dibagi menjadi dua, yaitu motivasi intrinsik dan ekstrinsik. Motivasi intrinsik yaitu jenis motivasi yang berhubungan dengan pemenuhan pribadi, kenikmatan dan kesenangan pribadi. Motivasi intrinsik membantu konsistensi individu dalam melakukan berbagai kegiatan yang efektif melalui tindakan sukarela. Motivasi ekstrinsik terjadi ketika orang-orang dipicu oleh faktor eksternal untuk mengeksplorasi atau menantang mereka untuk melakukan sesuatu dalam pencapaian reward.

\section{Kepuasan Kerja}

Robbins dan Judge (2008:107) kepuasan kerja menunjukan kesesuaian antara harapan seseorang yang timbul dan imbalan yang disediakan pekerjaan. Robbin (2010:118) juga mengatakan bahwa kepuasan kerja adalah suatu sikap umum terhadap pekerjaan seseorang sebagai perbedaan antara banyaknya ganjaran yang diterima pekerja dan banyaknya yang diyakini yang seharusnya diterima.

\section{Kinerja Karyawan}

Menurut Mangkunegara (2013:67) Kinerja adalah hasil kerja secara kualitas dan kuantitas yang dicapai oleh seorang pegawai dalam melaksanakan tugasnya sesuai dengan tanggung jawab yang diberikan kepadanya. Sedangkan menurut Wibowo (2010:9) kinerja merupakan gaya manajemen dalam mengelola sumber daya yang 
yang berorientasi pada kinerja yang melakukan proses komunikasi secara terbuka dan berkelanjutan dengan menciptakan visi bersama dan pendekatan strategis serta terpadu sebagai kekuatan pendorong untuk mencapai tujuan organisasi.

\section{Penelitian Terdahulu}

Penelitian terdahulu merupakan penelitian yang pernah dilakukan sebelumnya. Penelitian tersebut sangat penting untuk diungkapkan karena dapat digunakan sebagai sumber informasi dan bahan acuan yang sangat berguna bagi penelitian ini.

\begin{tabular}{|c|c|c|c|c|}
\hline No & $\begin{array}{c}\text { Peneliti dan } \\
\text { Tahun }\end{array}$ & Judul Penelitian & $\begin{array}{c}\text { Variable dan } \\
\text { Metode Analisis }\end{array}$ & Hasil Penelitian \\
\hline 1 & $\begin{array}{c}\text { Godi } \\
\text { Prakasa } \\
(2017)\end{array}$ & $\begin{array}{lr}\text { Pengaruh } & \text { Motivasi } \\
\text { Kerja } & \text { Terhadap } \\
\text { Kinerja } & \text { Pegawai } \\
\text { Dengan } & \text { Kepuasan } \\
\text { Kerja } & \text { Sebagai } \\
\text { Variabel } & \text { Mediasi } \\
\text { (Studi Kasus Pada } \\
\text { PT. PLN Area } \\
\text { Tanjung Karang. }\end{array}$ & $\begin{array}{l}\text { Independen : } \\
\text { Motivasi Kerja } \\
\text { Dependen : } \\
\text { Kinerja Pegawai } \\
\text { Mediasi : } \\
\text { Kepuasan Kerja } \\
\text { Analisis : SEM }\end{array}$ & 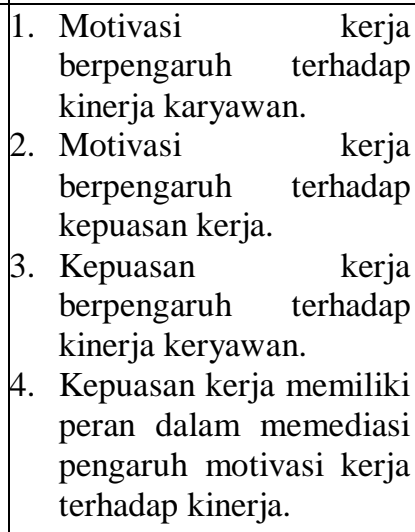 \\
\hline 2 & $\begin{array}{c}\text { Rahmawati } \\
\text { (2016) }\end{array}$ & 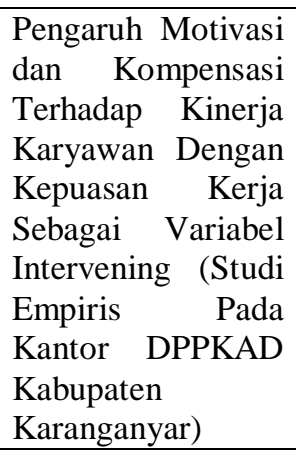 & $\begin{array}{l}\text { Independen : } \\
\text { Motivasi, } \\
\text { Kompensasi } \\
\text { Dependen : } \\
\text { Kinerja Karyawan } \\
\text { Intervening : } \\
\text { Kepuasan Kerja } \\
\text { Ananlisi : } \\
\text { Path Analisis } \\
\text { Regresi Linier }\end{array}$ & 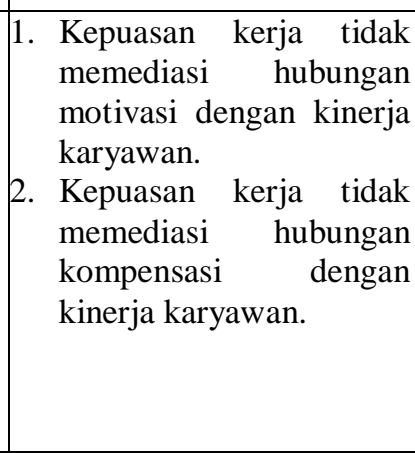 \\
\hline 3 & $\begin{array}{l}\text { Lusri dan } \\
\text { Siagian } \\
(2017)\end{array}$ & 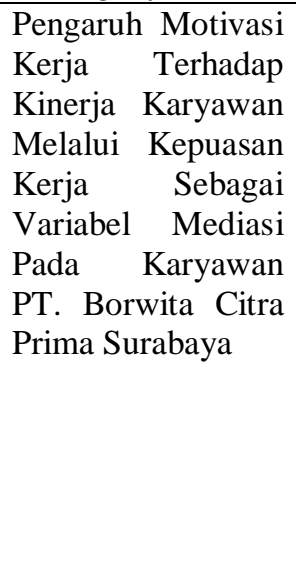 & $\begin{array}{l}\text { Independen : } \\
\text { Motivasi Kerja } \\
\text { Dependen : } \\
\text { Kinerja Karyawan } \\
\text { Mediasi : } \\
\text { Kepuasan Kerja } \\
\text { Analisis : Least } \\
\text { Partial Square (PLS) }\end{array}$ & 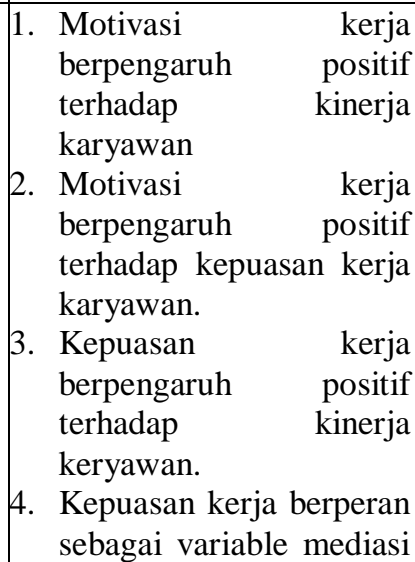 \\
\hline
\end{tabular}




\begin{tabular}{|c|c|c|c|l|}
\hline No & $\begin{array}{c}\text { Peneliti dan } \\
\text { Tahun }\end{array}$ & Judul Penelitian & \multicolumn{1}{|c|}{$\begin{array}{c}\text { Variable dan } \\
\text { Metode Analisis }\end{array}$} & \multicolumn{1}{|c|}{ Hasil Penelitian } \\
\hline & & & $\begin{array}{l}\text { antara motivasi kerja } \\
\text { tehadap kinerja } \\
\text { karyawan. }\end{array}$ \\
\hline
\end{tabular}

\section{Kerangka Konseptual}

Kerangka pikir adalah model konseptual tentang bagaimana teori berhubungan dengan berbagai faktor yang telah didefinisikan sebagai hal yang penting. Maka dapat digambarkan sebuah kerangka pikir sebagai berikut:

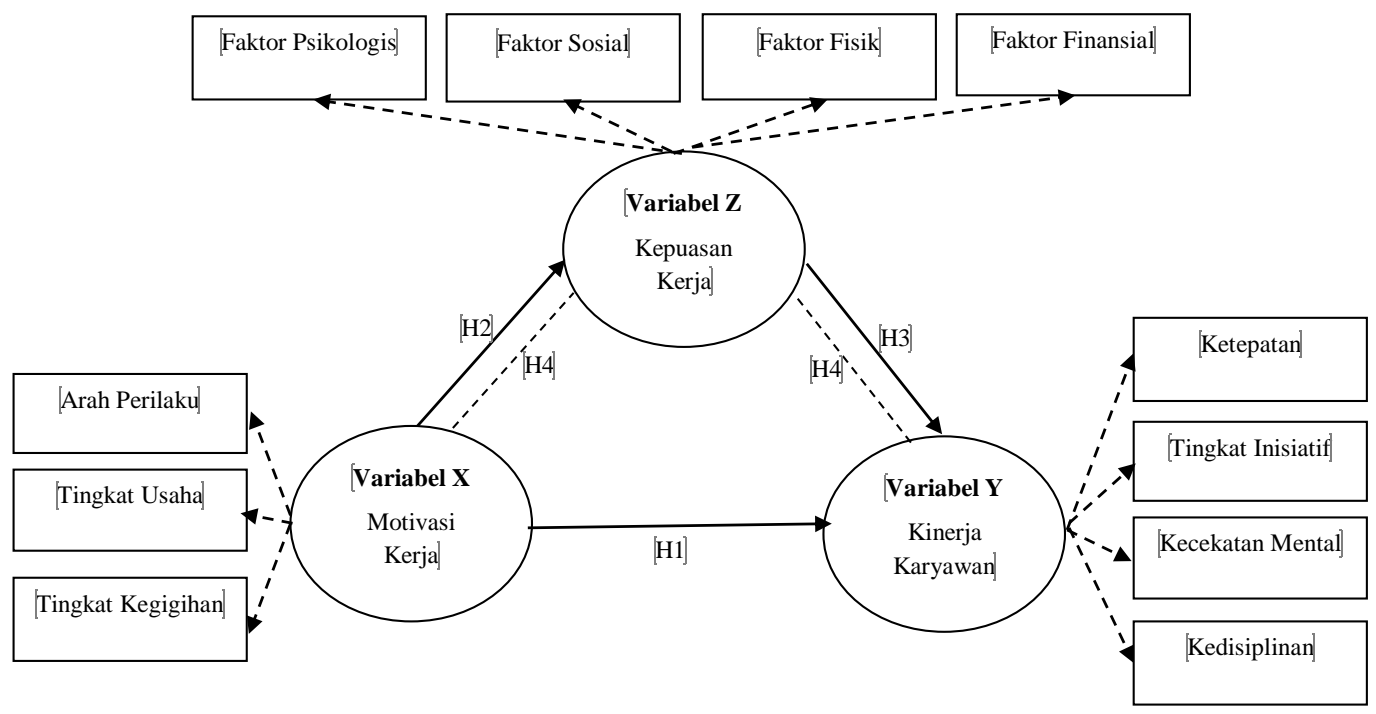

Gambar 1. Kerangka Konseptual

\section{Hipotesis}

a. Hipotesis 1 : Motivasi kerja berpengaruh terhadap kinerja karyawan pada PT. Federal International Finance Lampung Timur.

b. Hipotesis 2 : Motivasi kerja berpengaruh terhadap kepuasan kerja pada PT. Federal International Finance Lampung Timur.

c. Hipotesis 3 : Kepuasan kerja berpengaruh terhadap kinerja karyawan pada PT. Federal International Finance Lampung Timur.

d. Hipotesis 4 : Kepuasan kerja berperan sebagai variabel interveningg antara. motivasi kerja terhadap kinerja karyawan pada PT. Federal International Finance Lampung Timur. 


\section{Metode Penelitian}

\section{Definisi Operasional Variabel}

Adapun variabel penelitian ini terdiri dari tiga macam variabel, yaitu:

\section{Motivasi Kerja (Variabel X/ Variabel independen)}

Menurut Fernet (2012:208) motivasi adalah motif yang dikaitkan dengan keinginan seseorang untuk melakukan sesuatu atau tidak. Adapun indikator yang digunakan untuk mengukur motivasi kerja adalah:

1) Arah Perilaku

2) Tingkat Usaha

3) Tingkat Kegigihan

\section{Kepuasan Kerja (Variabel Z / Variabel Intervening)}

Kepuasan kerja menunjukan kesesuaian antara harapan seseorang yang timbul dan imbalan yang disediakan pekerjaan (Robbins dan Judge, 2008:107). Adapun indikator yang diukur adalah:

1) Faktor Psikologis

2) Faktor Sosial

3) Faktor Fisik

4) Faktor Finansial

\section{Kinerja Karyawan (Variabel Y / Variabel dependen)}

Kinerja adalah hasil kerja secara kualitas dan kuantitas yang dicapai oleh seorang pegawai dalam melaksanakan tugasnya sesuai dengan tanggung jawab yang diberikan kepadanya (Mangkunegara, 2013:67). Adapun indikator yang diukur adalah :

1) Ketepatan

2) Tingkat Inisiatif

3) Kecekatan Mental

4) Kedisiplinan waktu dan absensi,

\section{Teknik Pengumpulan Data}

Adapun teknik pengumpulan data yang digunakan dalam penelitian ini adalah angket dan dokumentasi. 


\section{Populasi, Sampel dan Teknik Pengambilan Sampel}

1. Populasi

Populasi dalam penelitian ini adalah seluruh karyawan yang ada di PT. Federal International Finance (FIF) 96 orang .

2. Sampel

Sampel dalam penelitian ini adalah seluruh karyawan yang ada di PT. Federal International Finance (FIF) yang berjumlah 96 orang.

\section{Teknik Analisis Data}

\section{Regresi Linier Sederhana}

Teknik analisis yang digunakan dalam penelitian ini adalah model regresi linear sederhana. Regresi linear sederhana digunakan untuk mengetahui Pengaruh Motivasi Kerja terhadap Kepuasan Kerja, Pengaruh Motivasi Kerja Terhadap Kinerja Karyawan, dan Pengaruh Kepuasan Kerja Terhadap Kinerja Karyawan pada PT. Federal International Finance (FIF).

Secara umum rumus dasar regresi sederhana yang digunakan adalah sebagai berikut ( Supranto, 2009:241) : $Y=a+b X$

Keterangan :

$\mathrm{Y} \quad=$ Variabel dependen

$\mathrm{X}=$ Variabel independent

a $\quad=$ Konstanta

$\mathrm{b} \quad=$ Koefisien-koefisien regresi

Untuk pengujian hipotesis dilakukan uji signifikasi koefisien regresi menggunakan rumus $\mathrm{t}$

\section{Path Analysis}

Koefisien jalur (path) adalah koefisien regresi yang distandarkan, yaitu koefisien regresi yang dihitung dari basis data yang telah diset dalam angka baku (Z-score).

Gambar 2.Model Analisis Jalur (Path Analysis) 


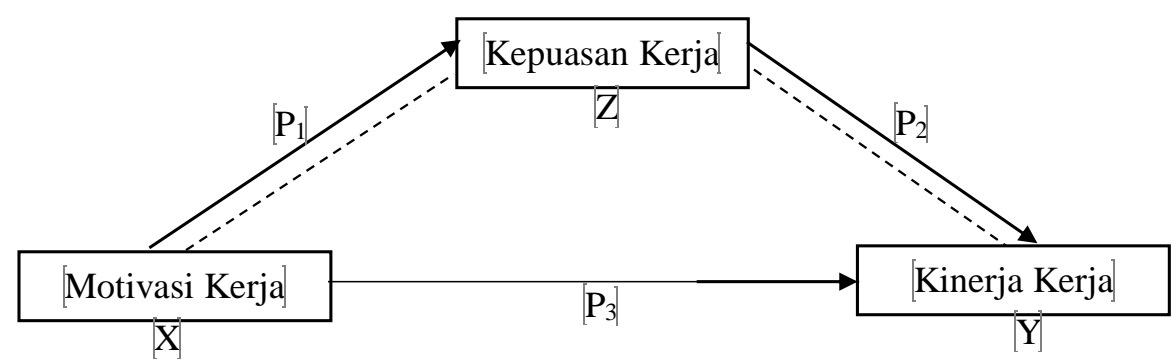

Berdasarkan gambar diatas selain nilai $\mathrm{P}$ menggambar jalur dan nilai koefisien jalur antar variabel. Dari diagram jalur diatas pula didapatkan persamaan strukturalnya yaitu terdapat tiga kali pengujian regresi sebagai berikut:
a. Pengaruh langsung $\mathrm{X}$ terhadap $\mathrm{Z}=\mathrm{a}+\mathrm{B}_{1} \mathrm{X}$
b. Pengaruh langsung $\mathrm{Z}$ terhadap $\mathrm{Y}=\mathrm{a}+\mathrm{B}_{2} \mathrm{Z}$
c. Pengaruh langsung $\mathrm{X}$ terhadap $\mathrm{Y}=\mathrm{a}+\mathrm{B}_{3} \mathrm{X}$
d. Pengaruh tidak langsung $X$ terhadap $Y$ melalui $Z=a+B_{1} X+B_{2} Z$

Keterangan :

$\begin{array}{ll}\mathrm{X} & \text { : Variabel independen yaitu Motivasi Kerja } \\ \mathrm{Y} & \text { : Variabel dependen yaitu Kinerja Karyawan } \\ \mathrm{Z} & \text { : Variabel intervening yaitu Kepuasan kerja } \\ \mathrm{a} & \text { : Koefisien konstanta } \\ \mathrm{B} & \text { : Koefisien regresi }\end{array}$

\section{Hasil Dan Pembahasan}

\section{Hasil Uji Regresi}

\section{Pengaruh Motivasi Kerja terhadap Kinerja Karyawan}

Tabel 2. Nilai koefisien regresi Motivasi Kerja terhadap Kinerja Karyawan Coefficientsa

\begin{tabular}{|c|c|c|c|c|c|}
\hline \multirow[b]{2}{*}{ Model } & \multicolumn{2}{|c|}{ Unstandardized Coefficients } & \multirow{2}{*}{$\begin{array}{c}\text { Standardized } \\
\text { Coefficients } \\
\text { Beta }\end{array}$} & \multirow[b]{2}{*}{$\mathrm{T}$} & \multirow[b]{2}{*}{ Sig. } \\
\hline & $\mathrm{B}$ & Std. Error & & & \\
\hline $1 \quad$ (Constant) & 25.878 & 5.587 & & 4.632 & .000 \\
\hline Motivasi Kerja & .393 & .146 & .360 & 2.696 & .000 \\
\hline
\end{tabular}

a. Dependent Variable: Kinerja Karyawan 
Tabel 2. Nilai koefisien regresi Motivasi Kerja terhadap Kinerja Karyawan Coefficientsa

\begin{tabular}{|c|c|c|c|c|c|}
\hline \multirow[b]{2}{*}{ Model } & \multicolumn{2}{|c|}{ Unstandardized Coefficients } & \multirow{2}{*}{$\begin{array}{c}\begin{array}{c}\text { Standardized } \\
\text { Coefficients }\end{array} \\
\text { Beta }\end{array}$} & \multirow[b]{2}{*}{$\mathrm{T}$} & \multirow[b]{2}{*}{ Sig. } \\
\hline & $\mathrm{B}$ & Std. Error & & & \\
\hline $1 \quad$ (Constant) & 25.878 & 5.587 & & 4.632 & .000 \\
\hline Motivasi Kerja & .393 & .146 & .360 & 2.696 & .000 \\
\hline
\end{tabular}

Pada tabel diatas dapat diketahui nilai signifikasi untuk motivasi kerja adalah 0.000 nilai tersebut lebih kecil dari 0.005 maka hipotesis yang menyatakan motivasi kerja berpengaruh terhadap kinerja karyawan pada PT. Federal International Finance Way Jepara tahun 2017, dapat diterima. Pada tabel diatas juga dapat diketahui nilai a adalah 25.878 dan nilai b adalah 0.393, dari nilai tersebut dapat dibuat persamaan $\mathrm{Y}=25.878+0.393 \mathrm{X}_{1}$. Koefisien regresi motivasi kerja $(b=0.393)$ menunjukkan bahwa kontribusi variabel motivasi kerja terhadap kinerja karyawan adalah positif, artinya jika faktor motivasi kerja ditingkatkan menjadi semakin baik sebesar satu satuan skor maka akan meningkatkan kinerja karyawan sebanyak 0.393 satuan skor dan sebaliknya jika terjadi penurunan satu satuan skor 0.393 maka akan menurunkan motivasi kerja sebesar 0.393 satuan skor.

Kemudian Koefisien Determinasi (KD) digunakan untuk mengetahui besarnya prosentase pengaruh antara motivasi kerja dengan kinerja karyawan. Hasil analisis dengan menggunakan program SPSS pada tabel berikut:

Tabel 3. Nilai koefisien determinasi

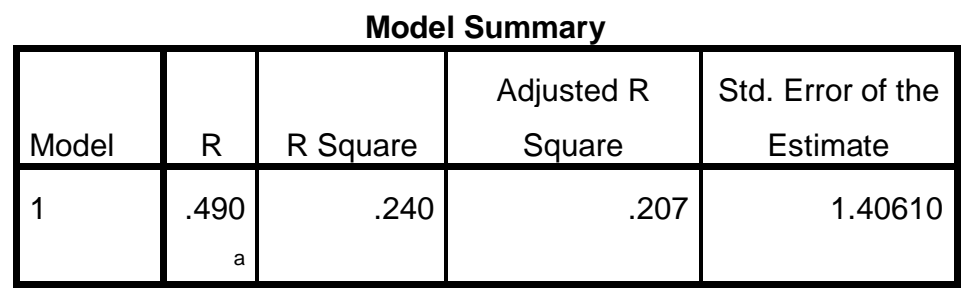

a. Predictors: (Constant), Motivasi kerja

Pengaruh motivasi kerja terhadap kinerja karyawan $\mathrm{R}$ Square $=0.240$ mempunyai arti bahwa kinerja karyawan dipengaruhi $24 \%$ oleh motivasi kerja dan selebihnya dipengaruhi faktor yang lain. 


\section{Pengaruh Motivasi Kerja terhadap Kepuasan Kerja}

Tabel 4. Nilai koefisien regresi Motivasi Kerja terhadap Kepuasan Kerja

Coefficients $^{a}$

\begin{tabular}{|c|c|c|c|c|c|}
\hline \multirow[b]{2}{*}{ Model } & \multicolumn{2}{|c|}{ Unstandardized Coefficients } & \multirow{2}{*}{$\begin{array}{c}\begin{array}{c}\text { Standardized } \\
\text { Coefficients }\end{array} \\
\text { Beta }\end{array}$} & \multirow[b]{2}{*}{$\mathrm{T}$} & \multirow[b]{2}{*}{ Sig. } \\
\hline & $\mathrm{B}$ & Std. Error & & & \\
\hline 1 (Constant) & 11.077 & 3.770 & & 2.938 & .007 \\
\hline Motivasi kerja & .733 & .098 & .841 & 7.447 & .000 \\
\hline
\end{tabular}

a. Dependent Variable: Kepuasan kerja

Pada tabel diatas dapat diketahui nilai signifikasi untuk motivasi kerja adalah 0.000 nilai tersebut lebih kecil dari 0.005 maka hipotesis yang menyatakan Motivasi kerja berpengaruh terhadap kepuasan kerja pada PT. Federal International Finance, dapat diterima. Pada tabel diatas juga dapat diketahui nilai a adalah 11.077 dan nilai $\mathrm{b}$ adalah 0.733 , dari nilai tersebut dapat dibuat persamaan $\mathrm{Y}=11.077+0.733 \mathrm{X}_{1}$. Koefisien regresi motivasi kerja $(b=0.733)$ menunjukkan bahwa kontribusi variabel motivasi kerja terhadap kepuasan kerja adalah positif, artinya jika faktor motivasi ditingkatkan menjadi semakin baik sebesar satu satuan skor maka akan meningkatkan kepuasan kerja sebanyak 0.733 satuan skor dan sebaliknya jika terjadi penurunan satu satuan skor 0.733 maka akan menurunkan motivasi kerja sebesar 0.733 satuan skor.

Kemudian Koefisien Determinasi (KD) digunakan untuk mengetahui besarnya prosentase pengaruh antara motivasi kerja dengan kepuasan kerja. Hasil analisis dengan menggunakan program SPSS pada tabel berikut:

Tabel 5. Nilai koefisien determinasi

\begin{tabular}{|c|c|c|c|c|}
\hline & & & Model Summary \\
Model & $\mathrm{R}$ & $\mathrm{R}$ Square & $\begin{array}{c}\text { Adjusted R } \\
\text { Square }\end{array}$ & $\begin{array}{c}\text { Std. Error of the } \\
\text { Estimate }\end{array}$ \\
\hline 1 & $.841^{\mathrm{a}}$ & .707 & .694 & .94884 \\
\hline
\end{tabular}

a. Predictors: (Constant), Motivasi kerja

Pengaruh motivasi kerja terhadap kepuasan kerja $\mathrm{R}$ Square $=0.707$ mempunyai arti bahwa kepuasan kerja dipengaruhi 70,7\% oleh motivasi kerja dan selebihnya dipengaruhi faktor yang lain. 


\section{Pengaruh Kepuasan Kerja terhadap Kinerja Karyawan}

Tabel 6. Nilai koefisien regresi Kepuasan Kerja terhadap Kinerja

Coefficients $^{\mathrm{a}}$

\begin{tabular}{|c|c|c|c|c|c|}
\hline \multirow[b]{2}{*}{ Model } & \multicolumn{2}{|c|}{ Unstandardized Coefficients } & \multirow{2}{*}{$\begin{array}{c}\text { Standardized } \\
\text { Coefficients } \\
\text { Beta }\end{array}$} & \multirow[b]{2}{*}{$\mathrm{T}$} & \multirow[b]{2}{*}{ Sig. } \\
\hline & $\mathrm{B}$ & Std. Error & & & \\
\hline 1 (Constant) & 24.727 & 6.712 & & 3.684 & .001 \\
\hline Kepuasan kerja & .414 & .171 & .450 & 2.415 & .024 \\
\hline
\end{tabular}

a. Dependent Variable: Kinerja karyawan

Pada tabel diatas dapat diketahui nilai signifikasi untuk kepuasan kerja adalah 0.000 nilai tersebut lebih kecil dari 0.005 maka hipotesis yang menyatakan kepuasan kerja berpengaruh terhadap kinerja karyawan pada PT. Federal International Finance Way Jepara tahun 2017, dapat diterima. Pada tabel diatas juga dapat diketahui nilai a adalah 24.727 dan nilai b adalah 0.414 , dari nilai tersebut dapat dibuat persamaan $\mathrm{Y}=24.727+0.414 \mathrm{X}_{1}$. Koefisien regresi kepuasan kerja $(b=0.414)$ menunjukkan bahwa kontribusi variabel kepuasan kerja terhadap kepuasan kerja adalah positif, artinya jika faktor kepuasan kerja ditingkatkan menjadi semakin baik sebesar satu satuan skor maka akan meningkatkan kinerja laryawan sebanyak 0.414 satuan skor dan sebaliknya jika terjadi penurunan satu satuan skor 0.414 maka akan menurunkan kepuasan kerja sebesar 0.414 satuan skor.

Kemudian Koefisien Determinasi (KD) digunakan untuk mengetahui besarnya prosentase pengaruh antara kepuasan kerja dengan kinerja karyawan. Hasil analisis dengan menggunakan program SPSS pada tabel berikut:

Tabel 7. Nilai koefisien determinasi

\begin{tabular}{|l|r|r|c|c|}
\hline & & Model Summary & \\
Model & $\mathrm{R}$ & $\mathrm{R}$ Square & $\begin{array}{c}\text { Adjusted R } \\
\text { Square }\end{array}$ & $\begin{array}{c}\text { Std. Error of the } \\
\text { Estimate }\end{array}$ \\
\hline 1 & $.450^{\mathrm{a}}$ & .202 & .168 & 1.44066 \\
\hline
\end{tabular}

a. Predictors: (Constant), Kepuasan kerja

Pengaruh kepuasan kerja terhadap kinerja karyawan R Square $=0.202$ mempunyai arti bahwa kinerja karyawan dipengaruhi 20,2\% oleh kepuasan kerja dan selebihnya dipengaruhi faktor yang lain. 


\section{Analisis Jalur (Path Analysis) Pengaruh motivasi kerja terhadap kinerja karyawan melalui kepuasan kerja sebagai variabel intervening.}

Analisis pengaruh motivasi kerja (x) terhadap kinerja karyawan (y) melalui kepuasan kerja (z), diketahui pengaruh langsung yang diberikan motivasi kerja (x) terhadap kinerja karyawan (y) (P3) adalah sebesar 0,360. Sedangkan pengaruh tidak langsung motivasi kerja (x) terhadap kinerja karyawan (y) melalui kepuasan kerja (z) adalah perkalian antara nilai beta motivasi kerja $(\mathrm{x})$ terhadap kepuasan kerja (z) (P1) dengan nilai beta kepuasan kerja (z) terhadap kinerja karyawan (y) (P2) yaitu : P1 x P2 = 0,841 x 0,450=0,378.

Untuk pengaruh total adalah penjumlahan dari pengaruh langsung (P3) dengan pengaruh tidak langsung $(\mathrm{P} 1 \times \mathrm{P} 2)$ yaitu $: \mathrm{P} 3+(\mathrm{P} 1 \times \mathrm{P} 2)=0,360+0,378$ $=0,738$.

Dari analisis diatas dapat diketahui bahwa nilai pengaruh langsung sebesar 0,360 dan pengaruh tidak langsung 0,378 yang berarti bahwa nilai pengaruh tidak langsung lebih besar dibandingkan dengan nilai pengaruh langsung. Hasil ini menunjukkan bahwa secara tidak langsung motivasi kerja melalui kepuasan kerja berpengaruh signifikan terhadap kinerja karyawan. Maka hipotesis yang menyatakan kepuasan kerja berperan sebagai variabel interveningg antara motivasi kerja terhadap kinerja karyawan pada PT. Federal International Finance Way Jepara dapat diterima.

\section{Kesimpulan}

Berdasarkan hasil penelitian dan pembahasan mengenai pengaruh motivasi kerja terhadap kinerja karyawan melalui kepuasaan kerja sebagai varibael intervening pada PT. FIF, maka dapat disimpulkan sebagai berikut :

1. Motivasi kerja berpengaruh terhadap kinerja karyawan pada PT. Federal International Finance.

2. Motivasi kerja berpengaruh terhadap kepuasan kerja pada PT. Federal International Finance.

3. Kepuasan kerja berpengaruh terhadap kinerja karyawan pada PT. Federal International Finance. 
4. Kepuasan kerja berperan sebagai variabel interveningg antara motivasi kerja terhadap kinerja karyawan pada PT. Federal International Finance.

5. Motivasi kerja berpengaruh terhadap kinerja karyawan secara langsung, akan tetapi motivasi kerja akan lebih besar nilai pengaruhnya terhadap kinerja karyawan apabila melalui atau ditambah dengan kepuasan kerja terlebih dahulu.

Berdasarkan kesimpulan yang telah dikemukakan diatas maka penulis mengajukan saran yang dapat dipertimbangkan oleh Perusahaan dan Karyawan yaitu:

1. Perusahaan sebaiknya lebih memperhatikan karyawannya, salah satunya dengan memberikan motivasi kerja, sehingga akan mendorong kinerja karyawan yang lebih baik.

2. Perusahaan sebaiknya lebih memperhatikan kesejahteraan karyawannya berupa pemberian imbal balik seperti promosi, tunjangan, dan juga hubungan antara karyawan dengan atasan dan hubungan sesame karyawan sehingga dapat memunculkan kepuasan kerja. Ketika kepuasan kerja meningkat makan kinerja karyawan akan meningkat juga.

Karyawan sebaiknya lebih giat lagi dalam pekerjaan dan tugas yang telah diamanahkan kepadanya, bila semua tugas dan pekerjaan dapat dijalankan secara optimal, perusahaan pasti akan memberikan imbal balik yang sepadan.

\section{DAFTAR PUSTAKA}

Ardana.2012. Manajemen Sumber Daya Manusia. Edisi pertama. Graha ilmu. Yogyakarta

Chrisnanda, Dody. 2017. Pengaruh Motivasi Kerja Terhadap Kinerja Karyawan

Di PT. Mas Sumbiri. Skripsi Manajemen Universitas Sanata Dharma Yogyakarta

Darmawan, D. H. 2013. Prinsip-Prinsip Perilaku Organisasi. Pena Semesta: Surabaya

Ferdinand, A. 2010. Metode Penelitian Manajemen Edisi 2. BP Universitas Diponegoro. Semarang 
Fernet 2012. predicting intra-individual changes in teacher burnout: The role of perceived school environment and motivational factors. Teaching and teacher education. Vol 28. pp. 514-525.

George, J.M., \& Jones, G. 2005. Understanding and Managing Organizational Behavior. Upper Saddle River. New Jersey.

Ghozali, I. 2010. Aplikasi Analisis Multivariate dengan Program SPSS. BP Universitas Diponegoro. Semarang.

Hendrawan, Aditya dan Ari Pradhanawati. 2015. Pengaruh Motivasi Kerja Terhadap Kinerja Karyawan Melalui Disiplin Kerja Sebagai Variabel Intervening. Jurnal Penelitian Vol.6 No.1, tahun 2017.

Luthans, Fred. 2009. Organizational Behavior Tenth Edition. mcgraw-hill book. Singapore.

Mangkunegara, A. P. 2013. Manajemen Sumber Daya Manusia Perusahaan. PT. Remaja Rosdakarya. Bandung.

Moeheriono.2010.Pengukuran Kinerja Berbasis Kompetensi. Ghalia Indonesia. Bogor

Nasution. 2008. Metode Research, Penelitian Ilmiah, Thesis. Jemmars. Bandung Prakasa, Godi. 2017. Pengaruh Motivasi Kerja Terhadap Kinerja Pegawai Dengan Kepuasan Kerja Sebagai Variabel Mediasi (Studi Kasus pada PT. PLN Area Tanjung Karang). Tesis Magister Manajemen Univeristas Lampung.

Robbins, SP dan. Judge TA. 2008. Prilaku Organisasi. Edisi-2 Buku 1. Salemba Empat. Jakarta.

Robbins, Stephen P. 2010. Organizational Behavior Concepts, Controversies, Application”. Eaglewoods Cliffs - Prentice Hall Inc.

Sani, Achmad dan Vivin Maharani. 2013. Metodologi Penelitian Manajemen Sumber Daya Manusia (Teori, Kuisioner dan Analisis Data). UIN MALIKI Press. Cetakan ke-2. Malang

Sarwono, Jonathan. 2007. Analisis Jalur Untyk Riset Bisnis Dengan SPSS. Penerbit Andi. Yogyakarta

Sugiyono 2013. Metode Penelitian Pendidikan (pendekatan kuantitatif, kualitatif, dan RdanD). Alfabeta. Bandung . 
Sugiyono. 2010. Metode Penelitian Administrasi. Alfabeta. Bandung. Suparyadi, H. 2015. Manajemen Sumber Daya Manusia Menciptakan Keunggulan Bersaing Berbasis Kompetensi SDM. C.V Andi Offset. Yogyakarta.

Supranto, J. 2009. Statistik Teori dan Aplikasi, Edisi ketujuh. Erlangga. Jakarta. Sutrisno, Edi. 2016. Manajemen Sumber Daya Manusia. Prenada Media. Jakarta. Suwondo, D. I., \& Sutanto, E. M. 2015. Hubungan Lingkungan Kerja, Disiplin Kerja, dan Kinerja Karyawan. Jurnal Manajemen Dan Kewirausahaan, 17(2), 135-144. https://doi.org/10.9744/jmk.17.2.135

Wibowo, Edi dan Susilowati. 2010. Pengaruh Kepemimpinan, Organizational, citizenship behavior, dan komitmen organisasional terhadap kepuasan kerja pegawai. Jurnal ekonomi dan kewirausahaan vol. 10, No. 1 pp 66-73

Wibowo. 2010. Manajemen Kinerja. Rajawali Press. Jakarta 